Original Article

\title{
POPULATION STRUCTURE OF KAEMPFERIA GALANGA L. FROM EASTERN INDIA
}

\author{
REENA PARIDA, SUJATA MOHANTY, SANGHAMITRA NAYAK \\ Centre for Biotechnology, SPS, Siksha ‘O’ Anusandhan University, Bhubaneswar, Odisha, India \\ Email: ms.reenas@gmail.com
}

Received: 07 Dec 2018 Revised and Accepted: 26 Jan 2019

\begin{abstract}
Objective: India has been a producer of a large number of aromatic medicinal plants which serves as a valuable genetic resource for future quality improvement to meet the ever-growing demand of human essential products. Thus, an urgent need arises for germplasm conservation of these high yielding varieties to help the pharmaceutical and other industries. For this understanding, the population structure is essential in order to explore
\end{abstract} their genetic identification by fingerprinting and molecular characterization.

Methods: In the present study DNA was isolated using modified Cetyl Trimethyl Ammonium Bromide (CTAB) method and Polymerase Chain Reaction (PCR) was performed according to standardized method along with its data analysis. This study was undertaken to characterize the highly medicinal Kaempferia galanga collected from 4 different populations of Odisha using the molecular markers as Random Amplified Polymorphic DNA and Inter-Simple Sequence Repeats for the first time.

Results: A dendrogram constructed through Sequential Agglomerative Hierarchical and Nested (SAHN) clustering and Unweighted Pair Group Method with Arithmetic mean (UPGMA) analysis showed an average similarity of 0.993 ranging between 0.967 to 1.000 . Jaccard's similarity coefficient of combined markers segregated the genotypes into two main clusters, 1 with six samples and the others at 0.98 similarity coefficient.

Conclusion: Hence, the molecular analysis could be further used for the identification of important novel gene present in Kaempferia galanga which can be utilized for future crop improvement as well as pharmacological activities.

Keywords: Kaempferia galanga, Polymerase Chain Reaction, Random Amplified Polymorphic DNA, Inter-Simple Sequence Repeats

(C) 2019 The Authors. Published by Innovare Academic Sciences Pvt Ltd. This is an open access article under the CC BY license (http://creativecommons.org/licenses/by/4.0/) DOI: http://dx.doi.org/10.22159/ijpps.2019v11i3.31226

\section{INTRODUCTION}

Kaempferia galanga L. (Zingiberaceae) an important medicinal herb is distributed in Asia and Africa [1]. Kaempferia galanga locally known as 'gandhasunthi' is famous as a health-promoting herb used in ayurvedic drugs, perfumery, cosmetic industries and as spice ingredients [2-5]. The plants have handsome, showy flowers and foliage due to their arching form and shining leaves and are cultivated as ornamentals. The plant stays close to the ground achieving a height of 3 inches, no central stem and its leaves just grow right off the rhizomes up to 6 inches. The plant blossoms with small white fragrant flowers with a splash of purple at the center but lasts only for a few hours. Leaves are used to flavour foodstuffs, mouthwashes possessing antioxidant, antinociceptive and antiinflammatory activities [6, 7]. The rhizomes are used to treat piles, tumours, coughs, epilepsy, asthma, spleen disorders, fever, abdominal pain, toothache, flatulence and anti-food-borne bacteria [8-9]. Natural sunscreens and Sun Protection Factor (SPF) boosters, a natural material that protects from Ultra Violet (UV) rays also isolated from Kaempferia galanga has been reported. This plant is economically important having a price value of Rs.300/Kg in dry rhizomes whereas its oil is US\$ $700 / \mathrm{Kg}$ internationally and is used by tribal and pharmaceuticals. The plant is conventionally propagated by rhizome with very low multiplication rate. Also due to demand and depletion of this highly valued medicinal plant, it is decreasing naturally and being recognized as an endangered [10]. The taxonomic identification of Kaempferia is difficult without its floral parts due to the problem in its morphological similarity with other related Zingiberaceae species. This paper aims the novelty of steps taken to identify the Kaempferia galanga species in molecular level present in various places of eastern India which is not yet reported. The species after identification could be used for various activities testing by the pharmaceutical industries and others to be used as medicines. This technique could further help in multiplication and conservation of the plant to fulfil the evergrowing human demand.

\section{MATERIALS AND METHODS}

Plant sample collection and molecular analysis

Kaempferia galanga were collected from the wild habitats of Koraput (18 ${ }^{\circ} 82^{\prime}$ N, $82^{\circ} 72^{\prime}$ E), Rourkela (22 ${ }^{\circ} 25^{\prime}$ N, $85^{\circ} 00^{\prime}$ E), Mayurbhanj (21 ${ }^{\circ} 93^{\prime} \mathrm{N}, 86^{\circ} 73^{\prime} \mathrm{E}$ ) and Jagatsinghpur population (20 ${ }^{\circ} 16^{\prime} \mathrm{N}, 86^{\circ} 10^{\prime} \mathrm{E}$ ) of Odisha. DNA isolation from fresh $2 \mathrm{gm}$ of leaves was done by Doyle and Doyle method [11]. Polymerase Chain Reaction (PCR) techniques namely Random Amplified Polymorphic DNA (RAPD) and Inter-Simple Sequence Repeats (ISSR) were done $[12,13]$. RAPD primers (Operon Tech., Alameda, USA) were dissolved in double sterilized $\mathrm{T}_{10} \mathrm{E}_{1}$ buffer, $\mathrm{pH} 8.0$ to the working concentration of $15 \mathrm{ng} / \mu \mathrm{l}$. 19 RAPD primers as per banding pattern were selected namely A4, A7, A9, A18, C2, C5, C11, D3, D7, D8, D12, D18, D20, N4, N16, N18, AF5, AF14 and AF15. 9 ISSR primers similarly used as (GAC) $5,(\text { GTGC })_{4},(\text { GACA })_{4},(\mathrm{AGG})_{6},(\mathrm{GA})_{9} \mathrm{~T}$ T(GA) ${ }_{9},(G T G)_{5},(G G A)_{4}$ and (CAA) $)_{5}$ from Bangalore Genei Pvt. Ltd, India. PCR product for both RAPD and ISSR was electrophoresed with $1.5 \%$ and $2 \%$ agarose gel and ethidium bromide at 60 volts for three hours. These were visualized in UV-transilluminator (BioRad, USA) and gel documented in Gel Documenting System (Bio-Rad, USA) for band details.

\section{Data scoring}

The scoring of bands as ' 1 ' and ' 0 ' for presence and absence of amplified products was done [14].

\section{Statistical analysis}

Resolving power (Rp) and Primer Index (PI)

$\mathrm{Rp}$ of both were calculated as $\mathrm{Rp}=\Sigma \mathrm{IB}$ (IB (Band informativeness) $=$ $1-[2 \times(0.5-\mathrm{P})], \mathrm{P}$ is the proportion of species containing band [15]. P I was calculated from the polymorphic index. The polymorphic index value was calculated as PIC $=1-\sum P^{2}{ }_{i}, P_{i}$ is the frequency of band of $i$ th allele [16]. In both cases, PIC was $1-p^{2}-q^{2}$, where $p$ is the frequency 
of band whereas q no frequency band [17]. PIC value calculated was primer index (PI). PI is the sum of PIC of all markers amplified by the same primer.

\section{Jaccard's similarity and bootstrapping}

Jaccard's similarity coefficient was measured by Unweighted Pair Group Method using Arithmetic averages (UPGMA) and Sequential Agglomerative Hierarchical and Nested (SAHN) [18-19]. The whole analysis was done using NTSYS-pc 2.02e [20]. A statistical testing of robustness as bootstrapping was performed for tree building.

\section{Chemicals and reagents}

RNase A (Qiagen Inc., USA)

RAPD operon primers (Operon Tech., Alameda, USA)

ISSR primers (Bangalore Genei Pvt. Ltd, Bangalore, India)

Taq DNA polymerase (Bangalore Genei Pvt. Ltd, Bangalore, India)

dNTP (MBI Fermentas, Lithuania)

6X loading dye (MBI Fermentas, Lithuania)

DNA ladder (MBI Fermentas, Lithuania)

Agarose (SRL Pvt. Ltd, India)

\section{RESULTS}

\section{PCR analysis}

25 RAPD primers were used but only 19 amplified. The four populations each in triplicates was used that produced distinct amplicons. 88 bands in total were amplified, 82 bands were monomorphic and 6 were polymorphic in nature. The highest band was 12 in OPD18, lowest was 1in OPD3 and no unique bands present. Average band per primer was 6.2. The resolving power was 2-22.83 where maximum and minimum was in OPD20 (22.83) and OPD3 (2) presented in table 1, fig. 2 a, b. 10 ISSR primers were used and 9 amplified in table 1. (GTGC)4, T(GA)9, (GTG) 5 and (CAA) 5 primers showed maximum bands as 9 but (GAC) 5 and (GACA) 4 showed minimum as 6 number. Band amplification ranged from 190-2450bp but no unique band seen and all were monomorphic in nature. The resolving power was maximum 18 in (GTGC)4, T(GA)9, (GTG)5 and minimum 12 in (GAC)5 and (GACA) 4 fig. 2 c, d.

\section{Combined markers analysis}

Total 158 bands were amplified in total where 152 were monomorphic and 6 polymorphic table 1 . Samples correlation was done with an average similarity of 0.993 ranging between 0.967 to 1.000. A dendrogram was constructed using Jaccard's similarity coefficient which resulted in 2 major clusters, 1 with six samples and the others at 0.98 similarity coefficient fig. 1 . Again these were subdivided into 2 subclusters, one containing the single sample and others in 2 subcluster. The Koraput and Mayurbhanj were present in Cluster I and Rourkela and Jagatsinghpur in Cluster II.

Table 1: Details of RAPD, ISSR and combined marker analysis as revealed among 4 populations of Kaempferia galanga

\begin{tabular}{|c|c|c|c|c|c|c|c|c|}
\hline Markers & Primer & $\begin{array}{l}\text { Sequence of } \\
\text { oligonucleotides }\end{array}$ & $\begin{array}{l}\text { Approx fragment } \\
\text { size (bp) }\end{array}$ & $\begin{array}{l}\text { Total } \\
\text { bands }\end{array}$ & $\begin{array}{l}\text { Monomorphic } \\
\text { bands }\end{array}$ & $\begin{array}{l}\text { Polymorphic } \\
\text { bands }\end{array}$ & $\begin{array}{l}\text { Unique } \\
\text { bands }\end{array}$ & $\begin{array}{l}\text { Resolving } \\
\text { power }\end{array}$ \\
\hline \multirow{14}{*}{ RAPD } & OPA4 & 5'AATCGGGCTG3' & $600-1400$ & 7 & 7 & 0 & 0 & 14 \\
\hline & OPA7 & 5'GAAACGGGTG3' & $750-2200$ & 8 & 8 & 0 & 0 & 16 \\
\hline & OPA18 & 5'AGGTGACCGT3' & $450-1700$ & 4 & 4 & 0 & 0 & 8 \\
\hline & OPC2 & 5'GTGAGGCGTC3' & $330-2250$ & 7 & 7 & 0 & 0 & 14 \\
\hline & 0PC5 & 5'GATGACCGCC3' & $900-2600$ & 7 & 7 & 0 & 0 & 14 \\
\hline & OPC11 & 5'AAAGCTGCGG3' & $1200-1550$ & 3 & 3 & 0 & 0 & 6 \\
\hline & OPD3 & 5'GTCGCCGTCA3' & 1031 & 1 & 1 & 0 & 0 & 2 \\
\hline & OPD7 & 5'TTGGCACGGG3' & $1031-2400$ & 5 & 5 & 0 & 0 & 10 \\
\hline & OPD8 & 5'GTGTGCCCCA3' & $700-2400$ & 7 & 7 & 0 & 0 & 14 \\
\hline & OPD18 & 5'GAGAGCCAAC3' & $220-1400$ & 12 & 8 & 4 & 0 & 20 \\
\hline & OPD20 & 5'ACCCGGTCAC3' & $500-2050$ & 10 & 10 & 0 & 0 & 22.8333 \\
\hline & OPN4 & 5'GACCGACCCA3' & $500-1650$ & 7 & 7 & 0 & 0 & 14 \\
\hline & OPN16 & 5'AAGCGACCTG3' & $100-800$ & 8 & 7 & 1 & 0 & 15 \\
\hline & OPN18 & 5'GGTGAGGTCA3' & $450-1300$ & 2 & 1 & 1 & 0 & 3 \\
\hline Total & & & & 88 & 82 & 6 & 0 & \\
\hline \multirow[t]{9}{*}{ ISSR } & SPS1 & $(\mathrm{GAC}) 5$ & $260-950$ & 6 & 6 & 0 & 0 & 12 \\
\hline & SPS2 & (GTGC) 4 & $190-1650$ & 9 & 9 & 0 & 0 & 18 \\
\hline & SPS3 & (GACA) 4 & $320-1150$ & 6 & 6 & 0 & 0 & 12 \\
\hline & SPS4 & (AGG)6 & $280-820$ & 7 & 7 & 0 & 0 & 14 \\
\hline & SPS5 & (GA)9T & $280-1350$ & 7 & 7 & 0 & 0 & 14 \\
\hline & SPS6 & $\mathrm{T}(\mathrm{GA}) 9$ & $250-1080$ & 9 & 9 & 0 & 0 & 18 \\
\hline & SPS7 & (GTG) 5 & $250-1080$ & 9 & 9 & 0 & 0 & 18 \\
\hline & SPS8 & (GGA)4 & $250-1750$ & 8 & 8 & 0 & 0 & 16 \\
\hline & SPS9 & (CAA) 5 & $575-2450$ & 9 & 9 & 0 & 0 & 18 \\
\hline Total & & & & 70 & 70 & 0 & 0 & 0 \\
\hline Grand tota & & & & 158 & 152 & 6 & 0 & \\
\hline
\end{tabular}

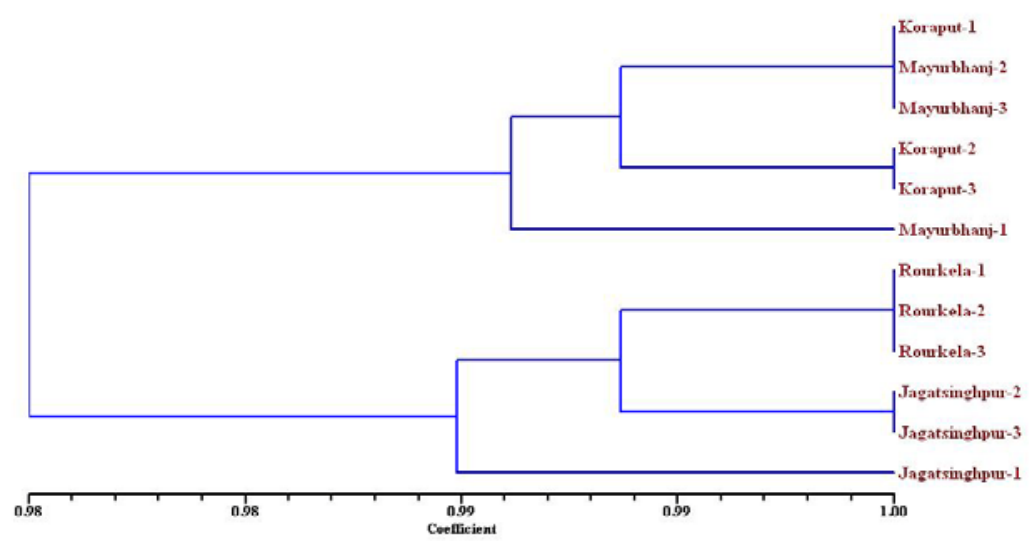

Fig. 1: Dendrogram showing genomic relationship within 4 populations in Kaempferia galanga as revealed from RAPD and ISSR analysis 


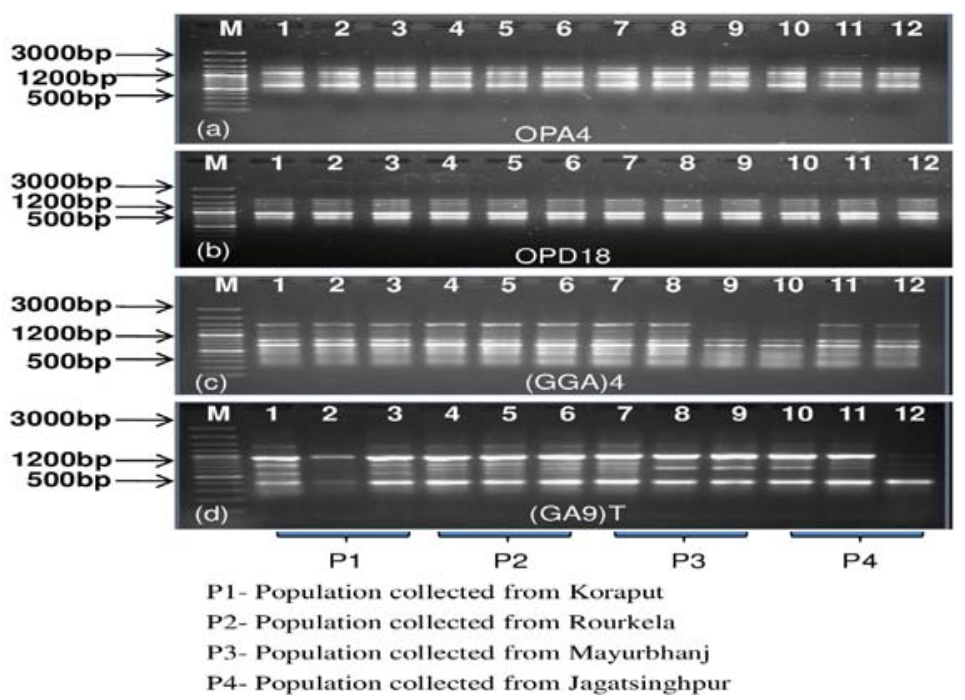

Fig. 2: (a, b) RAPD banding pattern and (c, d) ISSR banding pattern of Kaempferia galanga from different populations (Lane 1-12) and M-marker

\section{DISCUSSION}

Recently, emphasis on molecular markers has been increased for identification and characterization of genotypes, fingerprinting and cloning at the molecular level. The polymerase chain reaction-based techniques are widely used for genetic integrity and cost-effectiveness [21]. There are various reports on Zingiberaceous morphological analysis but few reports in its genetic level [22-23]. Few reports on the phylogeny of Zingiberaceae have been reported [24]. Also, other studies shows variation in their chloroplast DNA of 71 Kaempferia accessions as reported [25]. There are few other reports on genetic uniformity of cryopreserved Kaempferia galanga plantlets with minor variations [26]. There have been reports on the economic value, agronomy, ethnobotany, phytochemistry, pharmacology and conservation strategies [27]. The different populations having similarity within each other is grouped under the same cluster in our study is similar with other reports [28]. In their reports, 1accession from Bangladesh was identical with Pakistan and 2 accessions of Japan with China. Very few studies have been done on Kaempferia galanga and similar work by others [29-31]. The molecular analysis in the present work has proven to be useful in discrimination, characterization and differentiation of plant species by clustering them according to their origin. This indicates that combined markers provide a consistently good method for species identification than morphological characters. Genetic mapping of the genome could help in understanding their complex traits such as rhizome size, yield etc. which is useful for their breeding program.

\section{CONCLUSION}

The present study revealed moreover similarity among Kaempferia species based on its molecular data of different populations. Samples in single cluster reveal the closeness with each other but at the same time very few populations has been studied for which variation is negligible. This phylogenetic study could be valuable for Kaempferia galanga species identification from different regions of India, the exchange of healthy plant material for commercial exploitation in curing diseases.

\section{ACKNOWLEDGMENT}

We sincerely thank to Prof M. R. Nayak, President and Prof S. C. Si, Dean, Centre for Biotechnology, SPS, Siksha ' $O$ ' Anusandhan University for providing facilities and encouraging throughout the work.

\section{AUTHORS CONTRIBUTIONS}

Reena Parida, Sujata Mohanty under the guidance of Dr Sanghamitra Nayak designed the experiments, performed in the laboratory, analyzed the data proceeded by manuscript writing.

\section{CONFLICTS OF INTERESTS}

Declared none

\section{REFERENCES}

1. Chithra M, Martin KP, Sunandakumari C, Madhusoodanan PV Protocol for rapid propagation, to overcome delayed rhizome formation in field established in vitro derived plantlets of Kaempferia galanga L. Sci Hortic 2005;104:113-20.

2. Rahman MM, Amin MN, Ahamed T, Ali MR, Habib A. Efficient plant regeneration through somatic embryogenesis from leaf base derived callus of Kaempferia galangal L. Asian J Plant Sci 2004;3:675-8.

3. Sulaiman MR, Zakaria ZA, Duad IA, Hidayat MT. Antinociceptive and anti-inflammatory activities of the aqueous extract of Kaempferia galangal leaves in animal models. J Nat Med 2008;62:221-7.

4. Chan EWC, Lim YY, Wong SK, Lim KK, Tan SP, Lianto FS, et al. Effects of drying methods on the antioxidant properties of leaves and tea of ginger species. Food Chem 2009;113:166-72.

5. Sumazian Y, Syahida A, Hakiman M, Maziah M. Antioxidant activities, flavonoids, ascorbic acid and phenolic contents of Malaysian vegetables. J Med Plants Res 2010;4:881-90.

6. Sulaiman MR, Zakaria ZA, Duad IA, Hidayat MT. Antinociceptive and anti-inflammatory activities of the aqueous extract of Kaempferia galangal leaves in animal models. J Nat Med 2008;62:221-7.

7. Chan EWC, Lim YY, Wong SK, Lim KK, Tan SP, Lianto FS, et al. Effects of drying methods on the antioxidant properties of leaves and tea of ginger species. Food Chem 2009;1:166-72.

8. Kanjanpothy D, Kanjanapothi A, Panthong N, Lertprasertsuke T, Taesotikul C, Rujjanawate D, et al. Toxicity of crude rhizome extract of Kaempferia galanga L. (Proh Hom). J Ethnopharmacol 2004;90:359-65.

9. Wahab SI, Ain NM, Abdul AB, Elhassan MM, Ibrahim TA. Energy-dispersive X-ray microanalysis of elements content of medicinal plants used traditionally as anticancer cure. Res J Biol Sci 2009;4:547-9.

10. Shirin F, Kumar S, Mishra Y. In vitro plantlet production system for Kaempferia galanga, a rare Indian medicinal herb. Plant Cell Tiss Org Cult 2000;63:193-7.

11. Doyle JJ, Doyle JL. A rapid DNA isolation procedure for small quantities of fresh leaf tissue. Phytochem Bull 1990;19:11-5.

12. Williams JGK, Kubelik AR, Liva KJ, Rafalski JA, Tingey SV. DNA polymorphisms amplified by arbitrary primers are useful as genetic markers. Nucl Acid Res 1990;18:6531-5.

13. Zeitkiewicz E, Rafalski A, Labuda D. Genome fingerprinting by simple sequence repeat (SSR)-anchored PCR amplification. Genomics 1994;20:176-83.

14. Gherardi M, Mangin B, Goffinet B, Bonnet D, Huguet T. A method to measure genetic distance between allogamous populations of alfalfa (Medicago sativa) using RAPD molecular markers. Theor Appl Genet 1988;96:406-12. 
15. Prevost A, Wilkins MJ. A new system for comparing PCR primers applied to ISSR fingerprinting of potato cultivars. Theor Appl Genet 1999;98:661-8.

16. Smith JSC, Chin ECL, Shu H, Smith OS, Wall SJ, Senior ML, et al. An evaluation of the utility of SSR loci as molecular markers in maize (Zea mays L.): comparison of data from RFLPs and pedigree. Theor Appl Genet 1997;95:163-73.

17. Ghislain M, Zhang D, Fazardo D, Huamann Z, Hismans RH. Marker-assisted sampling of the cultivated andean potato Solanum fureja collection using RAPD markers. Genetic Res Crop Evol 1999;46:547-55.

18. Jaccard P. Nouvelles recherché sur Ia distribution florale. Bull Soc Vaudense Des Sci Naturelles 1908;44:223-70.

19. Sneath PHA, Sokal RR. Numerical Taxonomy, Freeman, San Francisco, California; 1973. p. 573.

20. Rohlf FJ. NTSYS-pc Numerical taxonomy and multivariate analysis system. Version 2.02e. Exeter Software, Setauket, New York; 1997

21. Reddy P, Sarla N, Siddiq EA. Inter-simple sequence repeat (ISSR) polymorphism and its application in plant breeding. Euphytica 2002;28:9-17.

22. Nayak S, Naik PK, Acharya LK, Mukherjee AK, Panda PC, Das P. Assessment of genetic diversity among 16 promising cultivars of ginger using cytological and molecular markers. Z Naturforsch 2005;60:485-92.

23. Sasikumar B. Genetic resources of Curcuma: diversity, characterization, and utilization. Plant Genetic Res 2005;3:23051.
24. Kress WJ, Prince LM, Williams KJ. The phylogeny and a new classification of the gingers (Zingiberaceae): evidence from molecular data. Am J Bot 2002;89:1682-96.

25. Techaprasan J, Klinbunga S, Ngamriabsakul C, Jenjittikul T. Genetic variation of Kaempferia (Zingiberaceae) in Thailand based on chloroplast DNA (psbA-trnH and petA-psb) sequences. Gen Mol Res 2010;9:1957-73.

26. Preetha TS, Hemanthakumar AS, Padmesh P, Krishnan PN. Genetic uniformity analysis of cryopreserved in vitro plantlets of Kaempferia galanga L.-an endangered medicinal species in tropical Asia. Indian J Biotech 2015;14:425-8.

27. Preetha TS, Hemanthakumar AS, Krishnan PN. A comprehensive review of Kaempferia galanga L. (Zingiberaceae): a high sought medicinal plant in tropical Asia. J Med Plant Stud 2016:4:270-6.

28. Jatoi SA, Kikuchi A, Yi SS, Naing KW, Yamanka S, Wataanbe JA, et al Use of rice SSR markers as RAPD markers for genetic diversity analysis in Zingiberaceae. Breeding Sci 2006;56:107-11.

29. Siriluck I, Ratchanok T, Worakij H, Thitamin K. Identification of 24 species of Zingiberaceae in Thailand using ISSR technique. Thai J Agric Sci 2014;1:1-6.

30. Amalia SK, Viktoria ME, Amarila M. Rapid PCR-based detection optimization of porcine DNA in the gelatin capsule shell. Int J Appl Pharm 2018;10:217-23.

31. Prabu P, Edayadulla N, Anand S. In vitro antibacterial activity and gas chromatography-mass spectrometry analysis of an ethanolic extract of leaves of Elettaria cardamomum L. maton. Asian J Pharm Clin Res 2019;12:73-5. 